\title{
谈水利工程造价全过程控制措施与管理
}

\author{
白春艳 \\ 乌鲁木齐水业集团有限公司 \\ DOI:10.32629/hwr.v4i6.3107
}

[摘 要] 如今,我国水资源与电力资源需求量明显增加,为加强水利工程全过程造价管理,提高水资源与电力资源运行的稳定性,及时解决我国 现阶段正在面临的能源危机,本文将重点分析水利工程造价全过程控制措施与管理,以供参考。

[关键词] 水利工程; 造价全过程控制; 措施与管理

水利工程建设中, 全过程造价控制可有效降低工程成本。为增大水利 工程的经济效益和社会效益, 应采取多种措施完善水利工程造价管理工作, 减少工程造价对工程进度、工程施工和工程成本的影响, 以加强水利工程 造价的科学性与合理性。

\section{1 水利工程造价全过程管理的意义}

水利工程造价管理是一种对工程建设中所需资金和资源的重要评估 方式, 现阶段, 水利工程建设规模明显扩大, 施工环节更加细化, 建设全过 程造价管理机制具有一定的现实意义。目前, 水利工程建设规模明显扩大, 施工中也广泛应用精细化管理模式。建设全过程工程造价管理体系有利于 增大企业的经济效益, 规避投资风险。且水利工程建设具有较强的不确定 性, 该特征也会加大企业建设的成本和费用。而全过程工程造价管理体系 可实现水利工程全过程管理, 加强工程建设的规范性, 最大限度地减少额 外支出。全过程工程造价管理体系可使企业严格执行工程预算编制, 在预 算监督的过程中也可及时发现工作中存在的各类不足, 及时解决工程施工 中存在的问题, 改进工程施工的质量。最后, 水利工程全过程管理体系能够 优化资源配置。在全过程工程造价管理体系落实的过程中, 可实现多要素 间的相互协调及配合。所以说, 工程造价是完善水利工程管理的有效途径。

\section{2 水利工程造价全过程控制现状分析}

近年来, 水利工程造价全过程控制管理受到人们的高度重视, 但是在 管理的过程中, 受多种因素的影响, 依然存在着十分明显的问题, 以下笔者 就将对水利工程造价全过程控制的现状及存在的问题展开具体论述。

2. 1 水里工程造价管理有待完善

现阶段的水利工程造价预算管理工作中, 受到监督不力和审核缺失等 因素的影响, 使得监管体系受到较大程度的影响。在水利工程造价预算编 制过程中, 受到审核不到位和审核人员素质不佳等因素的影响, 无法保证 审核流程的规范性, 而且也无法对材料和设备予以全面考核。

\section{2 该预算编制缺乏合理性}

水利工程造价预算管理中, 概预算编制工作对水利工程造价管理产生 了十分显著的影响, 预算编制人员忽视了概预算工作, 也就无法保障预算 编制的质量, 甚至出现了预算编制漏项和错项等问题, 最终极大地降低水 利工程造价管理水平。

\section{3受市场环境因素的制约}

市场环境的变化对水利工程造价预算具有十分显著的影响, 受市场客 观环境的限制, 出现超预算现象的概率较大。另外, 在市场环境变化中, 水 利工程无法及时应对市场变化。预算人员在开展前期准备工作时, 工作本 身覆盖的范围较广, 内容较多, 而工作人员未深入现场开展市场调查, 削弱 了判断的准确性, 最终影响到工程施工预算编制的质量。

\section{3 全过程的造价管理的有效策略}

为改变水利工程全过程造价管理的现状, 工作人员应结合现阶段水利
工程全过程造价管理中存在的问题, 采取科学有效的预防和处理措施, 以 此全面提升水利工程全过程造价控制及管理的综合水平。

3. 1 注重投资决策阶段的管理

其一, 资决策中, 工作人员要结合实际采取有效的综合管理方式。工程 施工前期, 工作人员要及时收集并整理材料, 之后工作人员需准确把握工 程施工的环境因素, 做好勘察与分析工作, 避免投资过程中出现明显的不 足。其二, 工作人员应主动了解并进入市场, 掌握工程施工材料和设备的市 场价格, 以此为依据加强工程管理。其三, 高度重视水利工程项目收益分析 工作, 基于科学和全面的分析后, 根据实际情况, 评估项目的风险性因素, 进而了解项目建设中可能获取的经济效益。

3.2 重视设计阶段的造价管理

水利工程决策后, 工程造价部门需充分结合决策方案完成设计方案的 编制工作。在以往的发展中, 经常忽视设计阶段的工程造价工作已然成为 较为普遍的问题。加强设计阶段的工程造价管理, 可严格控制工程造价, 提高工程造价管理的水平。完善工程设计阶段的工程造价可减少 3 成以上 的成本、设计阶段造价方案分析中, 建筑单位要以规范的工程招投标选择 优质的工程造价单位, 工程造价管理人员也需全面掌握和了解设计任务书 的主要内容, 参照实际选取合理的工程造价方法完成设计工作。

在水利工程设计中, 要求工程造价人员加强工程主材料的成本核算工 作, 且在计算中始终秉承利益最大化的原则, 依据施工组织设计方案确定 核算的结果。如工程造价人员要合理应用BIM技术, 发挥出该技术的优势作 用, 改进工程造价工作质量。除此之外, 工程造价人员还要与各部门展开沟 通和交流, 密切信息合作, 减少工程变更情况。如工程造价管理人员可在水 利工程设计中利用大数据平台, 将工程造价理念与设计阶段完美结合, 从 而加强水利工程造价控制的有效性。

3. 3加强施工全过程控制

水利工程项目建设期间, 施工投资尤为重要, 工作人员应当参照施工 环节及范围等诸多要素进行全方位分析, 加大对工程造价控制与管理规划 的落实力度。在遇到工程变更时, 还需采取科学有效的控制措施, 设计变 更、进度变更和施工条件变更则尤其如此。此外, 与建筑单位展开积极沟 通和交流, 深度掌握水利工程施工的地形条件及施工要求, 参照工程实际 做好备案记录, 为设计方案及施工图纸审查提供诸多的便利, 有效控制工 程变更, 以加强水利工程施工阶段造价管理与控制的规范性和有效性。

水利工程建设和施工阶段, 气候条件、施工图纸变更和合同条款均会 对工程施工产生较为显著的影响, 严重情况下还会引发索赔问题, 进而阻 碍水利工程施工阶段造价管理工作的开展。发生工程索赔问题时, 需及时 协调并沟通, 确保多个利益主体形成一致的意见, 依据合同规定有效处索 赔问题, 这样一方面可改进水利工程建设的质量, 另一方面也可维护多个 参建方的经济效益。 


\section{简析区域小型农田水利工程终端水价及农民承受力}

孙宏磊

塔城地区水利水电勘察设计院

DOI:10.32629/hwr.v4i6.3085

[摘 要] 在农田水利工程项目建设完成以后,要想保证工程项目能够得到长远稳定的运作,也需要制定合理的水价制度体系。在制定工程终端 水价的时候,应该做好供水成本与农民承受力之间的平衡,才能够促使水利工程取得较好的战略运作效果。本文先阐述了我国小型农田水利工程 的终端水价与农民承受力之间的关系, 接着详细探索了农田水利工程终端水价的合理制定方法, 最终立足于农民承受力水平, 全方位探讨了农田 水利工程终端水价制定的优化措施,有利于农田水利工程项目发挥较好的战略成效。

[关键词] 农田水利工程; 终端水价; 农民承受力; 水价调整

在小型农田水利工程项目运营发展过程中, 水价是一种非常关键的管 理方式, 能够较好实现水资源优化配置与高效应用。在最近多年时间里, 我国很多地区都开始加强水利工程终端水价的管理。比如在部分水资源比 较匮乏的区域开始贯彻季节性差价模式等。虽然我国各个地区都在结合本 区域实际情况进行水利工程终端水价的调整, 但是结合当前的实际情况来 看, 很多地区的水利工程终端水价都还存在着价格制定不合理、水价调整 不灵活等各类情况, 使得区域农民群体可能负担过高的水价成本, 不利于 水利工程项目的长远发展。

\section{1 小型农田水利工程终端水价与农民承受力的关系分析}

对于各个小型农田水利工程项目来说, 终端水价水平主要由三个部 分组成, 即水利工程自身建设运营成本、水资源成本和供水单位的盈利 需求。当前我国农田水利工程项目建设过程中, 都要投入较多的资源, 最 终的工程成本也比较高。这些成本都需要后期收取水价来偿还。在水资 源成本方面, 我国对于水资源拥有所有权, 因此农民群体使用水利工程 水资源需要付出一定的资金。即便是各类天然状态的水资源, 相关单位 在开发与使用这些水资源的时候, 都需要交纳一定的资源价值费用。在 供水单位盈利需求方面, 除了部分纯公益性的水利工程运营单位, 其他 供水单位在自身运营过程中都有一定的盈利需求, 才能够保证单位的长 远发展, 并给农田生产提供长期稳定的水资源, 但这部分费用可以得到 政府部门的补贴。

通过上述分析以后发现, 农田水利工程项目的终端水价受到多个方面 的因素影响。通过多个因素的分析也可以知道, 农田水利工程的成本比较

再者, 高度重视细节管理, 创建动态化的工程造价管理方式。水利工程 建设需要较长的时间, 所以, 在工程施工中, 人员要积极建立动态化的工程 造价模式, 根据过往的经验科学制定物资采购计划。现阶段, 我国各地也形 成了科学完善的工程建材单价信息表, 基于该信息表可及时准确地掌握建 材的市场价。为此, 造价管理人员需不断深化自身对信息表的认知能力, 结合最新的市场价格完善价格管理。此外, 合同管理也是施工阶段的重要 内容, 建立科学完善的合同条款可以完善工程造价管理工作。

3. 4 注重竣工阶段的管理

首先, 管理人员在管理的过程中, 采取全过程管理控制策略时, 要以工 程施工阶段作为切入点, 高度重视成本管理, 有效解决水利工程建设和施 工中出现的多种问题。借助全过程控制措施严格控制水利工程施工中的成 本投入, 以期有效降低工程造价。其次, 建筑单位还需高度重视竣工阶段的 管理。水利工程竣工后, 工作人员应充分结合工程投资概况和质量控制方 案, 制定完善的造价控制措施, 认真查看投资概况和建设成本的应用概况
高, 因此在制定终端水价的时候, 可能会制定一个相对较高的水价水平, 以 此来降低自己的成本负担。但农民群体自身的经济收入本身就不高, 同时 还有很多农民群体还是贫苦家庭。在这种情况下, 农民群体就无力承担较 高的终端水价。因此当水利工程项目制定相对较高终端水价的时候, 就会 直接引发农民群体跟水利工程项目之间的矛盾, 不利于水利工程在农田生 产过程中发挥较好的战略作用。在这种情况下, 我国农田水利工程在制定 终端水价的时候, 一定要充分关注农民群体的承受力水平, 同时还要立足 于此进行终端水价的优化调整。

\section{2 小型农田水利工程终端水价具体制定方法}

小型农田水利工程的终端水价确定方法相对来说是比较复杂的, 同时 由于各个地区自身实际情况有所差异, 因此具体方法可能还有一定的出 入。这里也结合山东地区的实际情况, 进行农田水利工程终端水价制定方 法的全面分析。

2. 1 灌溉定额分析

当前山东地区农田种植的农作物主要为小麦和玉米, 主要使用的灌溉 方式有三种, 即自流灌区、提水灌区和井灌区。在针对灌溉区域农作物种 植分类情况来看, 小麦和玉米所占的农田灌区面积比例都为 $75 \%$, 而蔬菜种 植面积占比则为 $15 \%$ 。在灌溉定额设计方面, 小麦所需要的灌溉水源最多, 接下来则为玉米、蔬菜等。对于技术人员来说, 需要结合实际灌区面积情 况, 设计小麦、玉米、蔬菜等各个农作物的灌溉用水系数, 最终结合不同农 作物种植面积就可以计算出灌溉定额情况。

2.2 终端水价的测算流程

及工程质量情况。

\section{4 结束语}

水利工程建设和施工十分复杂, 且工程施工内容较多, 采取有效措施 落实工程造价全过程管理与控制, 需要以工程设计、工程施工和工程竣工 作为立足点, 采取针对性的应对及控制措施, 贯彻落实工程造价控制与管 理规范, 大力维护水利工程项目建设的成果, 以增大水利工程项目的社会 效益和经济效益, 推动水利工程建设事业的稳定前行。

[参考文献]

[1]李晓程.水利工程造价管理中存在的问题与对策 [J].中华建 设,2019,(11):50-51.

[2]年海龙.水利工程造价在各个阶段的控制管理措施[J]. 吉林农 业,2017,(11):76.

[3]晏绪文.水利工程造价管理中问题的解决对策 [J]. 长江技术经 济,2019,3(S1):38-40+60. 